\title{
Perbedaan Efektifitas antara Efedrin dengan Lidokain sebagai Premedikasi untuk Mengurangi Nyeri Lokal akibat Injeksi Propofol
}

\author{
Bayu Prihananto ${ }^{1}$, R. Th. Supraptomo ${ }^{2}$, Eko Setijanto ${ }^{2}$, Sugeng Budi Santosa ${ }^{2}$ \\ 1. Fakultas Kedokteran, Universitas Sebelas Maret \\ 2. Bagian Anestesi, Fakultas Kedokteran, Universitas Sebelas Maret
}

Korespondensi : bayuprihananto@gmail.com

\begin{abstract}
ABSTRAK
Latar Belakang. Propofol merupakan agen induksi anestesi yang sering digunakan secara luas. Hal ini dikarenakan waktu pulih sadar pendek dengan kembalinya reflekreflek kognitif, protektif dan psikomotor yang cepat. Propofol memiliki masalah lazim yang membuat pasien tidak nyaman karena nyeri pada lokasi injeksi. Berbagai metode sudah diteliti untuk mengurang nyeri dengan hasil yang berbeda-beda, yaitu dengan penggunaan obat lidokain, fentanil, efedrin, atau modifikasi non-farmakologis dengan mendinginkan atau menghangatkan, mendilusi propofol, atau menyuntikkan pada vena yang besar. Penelitian ini ditujukan untuk mengetahui perbedaan efektifitas efedrin dengan lidokain sebagai premedikasi untuk mengurangi nyeri lokal akibat injeksi propofol.

Metode. Penelitian ini adalah penelitian quasi eksperimental. Efedrin dan lidokain sebagai variabel bebas, sedangkan nyeri lokal sebagai variabel terikat. Pengambilan subjek dipilih dengan kriteria tertentu dengan teknik purposive sampling yang berjumlah 40 orang, kemudian dibagi menjadi dua kelompok perlakuan (lidokain atau efedrin). Setiap kelompok perlakuan diinjeksikan obat premedikasi (lidokain $2 \% 1 \mathrm{mg} / \mathrm{kgBB}$ atau efedrin $30 \mu \mathrm{g} / \mathrm{kgBB}$ ) intravena pada 60 detik sebelum induksi propofol. Pada saat induksi propofol nyeri lokal diukur dengan pengamatan formulir Visual Analog Scale (VAS) selama 30 detik. Data yang diperoleh dianalisis menggunakan uji fisher exact.

Hasil: kelompok lidokain memberikan hasil tidak nyeri $10 \%$, nyeri ringan $85 \%$, dan nyeri sedang 5\%. Kelompok efedrin memberikan hasil tidak nyeri $20 \%$ dan nyeri ringan $80 \%$. Tidak ada perbedaan bermakna efektifitas antara efedrin dengan lidokain sebagai premedikasi dalam mengurangi nyeri akibat injeksi propofol $(\mathrm{p}=0,661)$.

Simpulan: Tidak ada perbedaan efektifitas antara efedrin $30 \mu \mathrm{g} / \mathrm{kgBB}$ intravena dengan lidokain $1 \mathrm{mg} / \mathrm{kgBB}$ intravena sebagai premedikasi dalam mengurangi nyeri akibat injeksi propofol.
\end{abstract}

Kata Kunci: nyeri, propofol, efedrin, lidokain

\section{ABSTRACT}

Background. Propofol is an induction agent anesthesia that is used widely because has short recovery time of conscious with the fast return of cognitive, protective and psychomotor reflexes. Propofol has side effect which is pain on injection site. Various methods have been studied to reduce this prolem with different results, for example the use of lidocaine, fentanyl, ephedrine, or non-pharmacological modification by cooling or warming, diluting propofol, or injecting large veins. This study aimed to determine the difference in the effectiveness of ephedrine with lidocaine to reduce local pain due to propofol injection.

Method. The research is quasi experimental. Ephedrine and lidocaine as independent variables, while local pain as the dependent variable. Subjects were taken by purposive sampling technique with total number is 40 persons, then divided into two treatment groups (lidocainelephedrine). Each treatment group was injected premedicated drugs 
(lidocaine $2 \% 1 \mathrm{mg} / \mathrm{kgBW}$ or ephedrine $30 \mu \mathrm{g} / \mathrm{kgBW}$ ) intravenously at 60 seconds before propofol induction, local pain was measured with Visual Analog Scale (VAS) form for 30 seconds during propofol induction. The data obtained were analyzed using the fisher exact test.

Results: The results from lidocaine groups showed $10 \%$ painless, $85 \%$ mild pain, and 5\% moderate pain. Whilst, the ephedrine group showed $20 \%$ painless and $80 \%$ mild pain. There was no significant difference in effectiveness between ephedrine and lidocaine as premedication in reducing pain due to propofol injection $(p=0.661)$

Conclusion: There is no difference in effectiveness between ephedrine $30 \mu \mathrm{g} / \mathrm{kgBW}$ and lidocaine $1 \mathrm{mg} / \mathrm{kgBW}$ intravenous as premedication in reducing pain due to propofol injection.

\section{Keywords: pain, propofol, ephedrine, lidocaine}

\section{PENDAHULUAN}

Penelitian awal obat anestesi umum awalnya berfokus pada satu situs aksi biologis obat tersebut, kemudian digantikan dengan skema lebih kompleks mengarah pada target molekuler di beberapa sistem saraf pusat (SSP). ${ }^{1} \quad$ Propofol (Diprivan, diisopropylphenol) merupakan agen induksi anestesi intravena yang populer dan sering digunakan secara luas. ${ }^{2}$ Hal ini dikarenakan waktu pulih sadar yang singkat dengan kembalinya reflek-reflek kognitif, protektif dan psikomotor yang cepat. ${ }^{3}$ Mekanisme kerja propofol diduga melalui potensiasi dari arus klorida yang dimediasi melalui kompleks reseptor asam $\gamma$-aminobutirat . ${ }^{4}$

Penggunaan propofol yang luas masih memiliki masalah timbulnya nyeri pada lokasi injeksi yang membuat pasien tidak nyaman saat induksi anestesi. ${ }^{5}$ Insidensi timbulnya rasa nyeri saat injeksi propofol sekitar $70 \%$ apabila tidak ada premedikasi nyeri. Nyeri akibat propofol didefinisikan sebagai angialgia karena rasa nyeri yang melibatkan pembuluh darah. ${ }^{6}$ Nyeri tersebut bisa terjadi secara langsung dan tertunda setelah 10-20 detik. Nyeri secara langsung dikarenakan terjadi iritasi endotelium vena, sedangkan nyeri tertunda akibat dari pelepasan mediator seperti kininogen dari kaskade kinin. ${ }^{7}$ Kualitas rasa nyeri digambarkan tajam, sakit, atau terbakar, hal ini termasuk sebagai masalah ketujuh yang paling penting dalam anestesi klinis saat ini oleh American Anesthesiologists. ${ }^{8}$

Berbagai metode sudah dilakukan untuk mencegah nyeri akibat injeksi propofol dengan hasil yang bervariasi, yaitu dengan penggunaan obat anestesi lokal (lidokain), opiod (fentanil), metokloramid, ondasentron, atau modifikasi non-farmakologis dengan mendinginkan atau menghangatkan, mendilusi propofol, atau menyuntikkan pada vena yang besar. $^{6}$ Obat lain yang dipakai untuk mengurangi nyeri propofol tetapi masih jarang digunakan adalah efedrin. ${ }^{9}$

Efedrin adalah agen simpatomimetik yang digunakan secara luas sebagai stimulan adrenergik, aplikasi klinisnya sesuai dengan sifat farmakologisnya yang melakukan stimulasi pada reseptor $\alpha-, \beta 1-$, dan $\beta 2$ adrenergik baik efek langsung maupun tidak langsung. ${ }^{10}$ Mekanismenya dalam mengurangi nyeri propofol adalah dilepaskannya norepinefrin endogen dari tubuh yang akan mengurangi efek bradikinin yang timbul akibat injeksi propofol. ${ }^{11}$ Selain itu, efedrin berbeda dengan obat lain karena obat ini juga bisa digunakan untuk evaluasi bradikardihipotensi yang merupakan efek samping lain dari pengggunaan propofol. ${ }^{12}$

Lidokain merupakan obat anestesi lokal amida dan termasuk antiaritmia $1 \mathrm{~b}$. Obat ini dianggap sebagai obat essensial dalam daftar 
obat menurut WHO yang berkhasiat, hemat biaya, dan dapat digunakan di sistem pelayanan kesehatan apapun. ${ }^{13}$ Mekanisme aksi lidokain dalam mengurangi nyeri propofol adalah sebagai anestesi lokal dan mengurangi $\mathrm{pH}$ dari propofol apabila dicampur. ${ }^{14}$ Seperti anestesi lokal lain, lidokain bekerja melalui blokade reversibel pada propagasi impuls saraf, kemudian mengikat saluran natrium, menyebabkan perubahan formasi yang mencegah masuknya natrium sementara, sehingga depolarisasi rangsang nyeri yang terjadi pada vena perifer akan terputus dan tidak tersalurkan pada serabut saraf vena perifer. ${ }^{15}$

Berdasarkan hal di atas, maka peneliti tertarik untuk meneliti perbedaan efektifitas antara efedrin dengan lidokain sebagai premedikasi untuk mengurangi nyeri lokal akibat injeksi propofol.

\section{METODE}

Penelitian yang digunakan adalah penelitian eksperimental quasi dengan teknik purposive sampling. Penelitian ini dilakukan di Instalasi Bedah Sentral (I.B.S.) RSUD Dr. Moewardi pada minggu ke-2 Bulan September 2019 hingga terpenuhinya besar sampel. Prosedur dari penelitian ini sudah diterima oleh Komisi Etik Penelitian Kesehatan RSUD Dr. Moewardi dengan Surat Kelaikan Etik Nomor : 902 / VII / HREC / 2019. Surat kelaikan etik menunjukkan bahwa penelitian ini sudah memenuhi 7 butir standar kelaikan etik meliputi : 1 . Nilai Sosial/Klinis; 2. Nilai Ilmiah; 3. Pemerataan Beban dan Manfaat; 4. Potensi manfaat > resiko; 5. Bujukan/Eksploitasi/Inducement; 6. Rahasia dan Privacy; 7. Informed Consent/IC (Persetujuan Setelah Penjelasan/PSP).

\section{Subjek Penelitian}

Besar sampel yang digunakan adalah 40 orang, dibagi menjadi 2 kelompok, yaitu:

Kelompok I : 20 pasien diberi lidokain 2\% $1 \mathrm{mg} / \mathrm{kgBB}$ intravena
Kelompok II : 20 pasien diberi efedrin 30 $\mu \mathrm{g} / \mathrm{kgBB}$ intravena.

Empat puluh pasien, dengan 20 pasien setiap kelompoknya sudah memenuhi kriteria inklusi dan eksklusi. Kriteria inklusi yaitu pria atau wanita, usia 18-60 tahun, status fisik ASA I-II, pasien menyetujui informed consent. Kriteria eksklusi pasien mempunyai kontraindikasi dengan propofol, efedrin, dan lidokain, mengalami sindrom nyeri kronik sebelum injeksi propofol, pasien sedang memakai obat analgetik atau sedatif, pasien mengalami phlebitis. Kriteria drop out yaitu terdapat alergi dengan obat yang dipakai dalam penelitian, pasien tidak mengikuti cara kerja yang sudah ditentukan, pasien mengalami bradikardi setelah penyuntikan efedrin, tekanan darah pasien lebih dari 180/110 mmHg.

Sampel dibagi menjadi dua kelompok perlakuan. Kelompok perlakuan I diinjeksikan lidokain $2 \% 1 \mathrm{mg} / \mathrm{kgBB}$ intravena pada 60 detik sebelum induksi propofol, sedangkan kelompok II diinjeksikan efedrin $30 \mu \mathrm{g} / \mathrm{kgBB}$ intravena pada 60 detik sebelum induksi propofol. Pada saat induksi propofol nyeri lokal diukur dengan pengamatan formulir VAS selama 30 detik. Data yang diperoleh dianalisis menggunakan uji fisher exact.

\section{Variabel Penelitian}

Variabel yang diteliti adalah efedrin dan lidokain sebagai variabel bebas diujikan apakah memiliki perbedaan efektifitas sebagai premedikasi dalam mengurangi nyeri lokal akibat injeksi propofol sebagai variabel terikat. Nyeri lokal diukur dengan VAS. Interpretasi dari skala VAS sebagai berikut : Tidak Nyeri : >0 - <10 mm; Nyeri Ringan : $\geq 10$ - $30 \mathrm{~mm}$; Nyeri Sedang : >30 - $70 \mathrm{~mm}$; Nyeri Berat : > $70-90 \mathrm{~mm}$; Nyeri Sangat Berat : > $90-100 \mathrm{~mm}$. Selain itu, terdapat variabel luar yang dibedakan menjadi dua, yang pertama variabel luar terkendali yang terdiri dari jenis kelamin, usia, status fisik, dosis obat, tempat penyuntikan, dan cara 
Prihananto et. al., Perbedaan Efektifitas antara Efedrin dengan Lidokain sebagai Premedikasi untuk Mengurangi Nyeri Lokal akibat Injeksi Propofol

penyuntikan. Kemudian variabel luar yang tidak dikendalikan yang terdiri dari sensitivitas individu terhadap efek obat anestesi, pendarahan, dan kestabilan emosi. Nyeri akibat injeksi propofol adalah data sekunder yang didapatkan dari pengamatan formulir VAS. Pengamatan ini dilakukan selama 30 detik pada saat induksi propofol diinjeksikkan ke pasien, sehingga nyeri yang diukur benar-benar berasal dari injeksi propofol sebagai general anesthesia sebelum operasi dimulai. Apabila ada nyeri berasal dari penyakit pasien atau efek obat-obatan maka tidak akan dimasukkan ke dalam sampel karena memenuhi kriteria ekskulsi.

\section{Analisis Statistik}

Data yang diperoleh akan diolah menggunakan aplikasi SPSS diuji dengan fisher exact test untuk mencari pengaruh variabel bebas berupa efedrin dan lidokain terhadap variabel terikat berupa nyeri yang diukur dengan VAS. Data karakteristik kedua kelompok perlakuan dianalisis terlebih dahulu agar homogen sehingga layak untuk dibandingkan. Analisis statistik untuk umur dan berat badan menggunakan independent $t$ test, untuk jenis kelamin menggunakan uji chi square, sedangkan untuk ASA menggunakan uji fisher exact dengan mengambil tingkat kemaknaan $\mathrm{p}<0,05$.

\section{HASIL}

Empat puluh pasien dengan 20 pasien setiap kelompoknya terlibat dalam penelitian ini. Karakteristik subjek penelitian dapat dilihat pada Tabel 1. menjelaskan bahwa tidak ada perbedaan yang signifikan $(p>0,05)$ dalam umur, berat badan, jenis kelamin, dan status fisik ASA di antara kedua kelompok sehingga layak untuk diuji keefektifitasan antara efedrin dengan lidokain dalam mengurangi nyeri lokal akibat injeksi propofol.
Tabel 1. Karakteristik Subjek Penelitian

\begin{tabular}{cccc}
\hline Variabel & Lidokain & Efedrin & $\mathrm{p}$ \\
\hline $\begin{array}{c}\text { Umur } \\
\text { (tahun) }\end{array}$ & $46,2 \pm 11,06$ & $38,7 \pm 13,69$ & 0,064 \\
BB $(\mathrm{kg})$ & $61,25 \pm 10,55$ & $59,05 \pm 7,08$ & 0,444 \\
$\begin{array}{c}\text { Jenis } \\
\text { Kelamin } \\
\text { L }\end{array}$ & $10(25 \%)$ & $7(17,5 \%)$ & \\
P & $10(25 \%)$ & $13(32,5 \%)$ & 0,337 \\
ASA & & & \\
I & 0 & 20 & 0,147 \\
II & 2 & 18 & \\
\hline
\end{tabular}

Subjek penelitian yang menggunakan lidokain tidak nyeri sebanyak 2 orang (10\%), nyeri ringan sebanyak 17 orang (85\%), dan nyeri sedang sebanyak 1 orang (5\%). Sedangkan pada subjek penelitian yang menggunakan efedrin didapatkan pasien tidak nyeri sebanyak 4 orang (20\%) dan pasien yang mengalami nyeri ringan 16 orang $(80 \%)$.

Tabel 2. Hasil Sampling

\begin{tabular}{ccccc}
\hline $\begin{array}{c}\text { Nama } \\
\text { Obat }\end{array}$ & $\begin{array}{c}\text { Tidak } \\
\text { Nyeri }\end{array}$ & $\begin{array}{c}\text { Nyeri } \\
\text { Ringan }\end{array}$ & $\begin{array}{c}\text { Nyeri } \\
\text { Sedang }\end{array}$ & Total \\
\hline Lidokain & 2 & 17 & 1 & 20 \\
Efedrin & 4 & 16 & 0 & 20 \\
Total & 6 & 33 & 1 & 40
\end{tabular}

Hasil sampling dapat dilihat di Tabel 2. Dari data tersebut, dapat disimpulkan bahwa secara klinis efedrin lebih efektif dibandingkan lidokain dalam mengurangi nyeri lokal akibat injeksi propofol. Akan tetapi, setelah dilakukan analisis data secara statistik didapatkan hasil perhitungan uji fisher exact adalah 0,661. Hal tersebut menjelaskan bahwa tidak ada perbedaan bermakna $(p>0,05)$ efektifitas antara efedrin dengan lidokain sebagai premedikasi untuk mengurangi nyeri lokal akibat injeksi propofol. Tabel 3. menggambarkan hasil dari 
analisis data, didapatkan uji fisher exact 0,661 .

Tabel 3. Hasil Uji Fisher Exact

\begin{tabular}{cccc}
\hline Nama obat & $\begin{array}{c}\text { Tidak } \\
\text { Nyeri }\end{array}$ & Nyeri & $\mathrm{p}$ \\
\hline Lidokain & 2 & 18 & \\
Efedrin & 4 & 16 & 0,661 \\
& & & \\
\hline
\end{tabular}

\section{PEMBAHASAN}

\section{Karakteristik Sampel}

Pada penelitian ini dibandingkan efedrin dengan lidokain untuk mengetahui apakah ada perbedaan efektifitasnya untuk mengurangi nyeri lokal akibat injeksi propofol. Sebelum melakukan analisis data antara variabel bebas yaitu efedrin dan lidokain dengan variabel terikat yaitu intensitas nyeri yang diukur dengan visual analog scale (VAS), dilakukan terlebih dahulu usaha homogenisasi pada subjek. Dua kelompok perlakuan dilakukan uji homogenitas untuk dilihat apakah terdapat perbedaan secara bermakna agar dapat dibandingkan. Karakteristik subjek penelitian meliputi jenis kelamin, umur, berat badan, dan status fisik ASA didapatkan hasil nilai $\mathrm{p}>$ 0,05 yang berarti tidak ada perbedaan bermakna secara statistik antara dua kelompok.

Jenis kelamin memiliki hubungan dengan intensitas nyeri injeksi propofol. Korelasi menunjukkan bahwa pasien pria memiliki insiden nyeri injeksi yang lebih rendah daripada pasien wanita karena efek mekanis bahwa laki-laki memiliki vena berukuran lebih besar daripada perempuan. Selain itu, wanita dinilai lebih sensitif dan kurang mentoleransi nyeri dibandingkan pria. ${ }^{16}$ Pada penelitian ini kelompok perlakuan I (lidokain) terdiri dari 10 pasien laki-laki dan 10 pasien perempuan, sedangkan kelompok perlakuan II terdiri dari 7 pasien laki-laki dan 13 pasien perempuan. Sebelum menguji perbedaan efektifittas antara lidokain dan efedrin sebagai premedikasi, kelompok perlakuan I dan II diuji dahulu homogenitasnya dengan uji statistik. Uji statistik yang digunakan adalah uji chi square dan didapatkan $\mathrm{p}=0,147$. Karena $\mathrm{p}>0,05$ maka tidak ada perbedaan secara statistik antara dua kelompok perlakuan sehinga dapat diuji perbedaan efektifitas antara kelompok perlakuan I (lidokain) dengan kelompok perlakuan II (efedrin).

Umur dan nyeri memiliki hubungan dimana insidensi nyeri lebih tinggi pada pasien usia muda. Pada anak-anak, semakin muda usianya, semakin tinggi insidensi dan keparahan nyeri pada injeksi propofol. ${ }^{17}$ Dijelaskan juga bahwa lanjut usia (lansia) berespon terhadap nyeri dapat berbeda dengan usia lebih muda karena nyeri dianggap sesuatu yang harus diterima sebagai proses penuaan. ${ }^{16}$

Berat badan atau BMI tidak memiliki korelasi yang signifikan terhadap insidensi atau intensitas nyeri akibat injeksi propofol. Penelitian ini menggunakan pasien dengan. ${ }^{17}$

Status fisik ASA I atau ASA II untuk meminimalisir faktor luar yang dapat mempengaruhi hasil penelitian karena kondisi fisik atau perubahan fisiologi yang diakibatkan oleh penyakit yang diderita pasien yang akan dimasukkan dalam penelitian.

\section{Analisis Hasil}

Sampel pada kelompok lidokain memberikan hasil tidak nyeri sebanyak 2 orang (10\%), nyeri ringan sebanyak 17 orang $(85 \%)$, dan nyeri sedang sebanyak 1 orang (5\%). Sedangkan pada sampel kelompok efedrin memberikan hasil tidak nyeri sebanyak 4 orang (20\%) dan pasien yang mengalami nyeri ringan 16 orang $(80 \%)$. Penggolongan intensitas nyeri menggunakan VAS.

Data yang diperoleh dianalisis dengan SPSS menggunakan metode uji fisher exact. Uji ini digunakan sebagai alternatif karena tidak memenuhi syarat uji chi square, dimana 
terdapat jumlah cell dengan frekuensi harapan yang kurang dari 5 lebih dari $20 \%$. Hasil uji fisher exact menunjukkan nilai-p 0,661. Hasil tersebut menunjukkan bahwa H0 diterima dan H1 ditolak karena nilai-p>0,05 sehingga dapat disimpulkan bahwa tidak ada perbedaan bermakna efektifitas efedrin dengan lidokain sebagai premedikasi untuk mengurangi nyeri lokal akibat injeksi propofol.

Hasil ini sesuai dengan penelitian sebelumnya, Mujahidin, Suryono, dan Uyun (2013) menyatakan bahwa pemberian efedrin $30 \mu \mathrm{g} / \mathrm{kgBB}$ intravena tidak terdapat perbedaan yang signifikan dibandingkan lidokain 2\% $40 \mathrm{mg}$ intravena untuk mencegah respon nyeri saat penyuntikan propofol 2 $\mathrm{mg} / \mathrm{kgBB}$ intravena. Penelitian yang dilakukan di RSUP Dr. Sardjito, Yogyakarta dan rumah sakit afiliasi menggunakan 128 pasien yang dibagi menjadi dua kelompok masing-masing kelompok 64 pasien. Penelitian yang menggunakan uji chi square ini menunjukkan hasil tidak ada perbedaan bermakna terhadap intensitas nyeri setelah pemberian infus intravena lidokain dibandingkan dengan efedrin $(\mathrm{p}=0,201) .{ }^{18}$

Keterbatasan dalam penelitian ini terletak pada jumlah sampel yang diuji. Selain itu, terdapat variabel luar tidak dikendalikan seperti sensitivitas individu terhadap efek obat anestesi, sensitivitas individu terhadap nyeri, pendarahan, dan kestabilan emosi.

\section{KESIMPULAN}

Dari hasil penelitian ini didapatkan bahwa tidak ada perbedaan bermakna efektifitas antara efedrin $30 \mu \mathrm{g} / \mathrm{kgBB}$ intravena dengan lidokain $1 \mathrm{mg} / \mathrm{kgBB}$ intravena sebagai premedikasi dalam mengurangi nyeri akibat injeksi propofol.

\section{UCAPAN TERIMA KASIH}

Penulis mengucapkan terima kasih kepada SMF Anestesiologi, Dokter dan perawat Instalasi Bedah Sentral, serta farmasi
RSUD Dr. Moewardi yang telah mendukung penelitian ini.

\section{DAFTAR PUSTAKA}

1. Katzung, Bertram G, Master, Susan B, Trevor, Anthony J. Farmakologi Dasar dan Klinik Edisi 12. Jakarta:EGC;2012.pp.480;490.

2. Saad, Ali. Debate of using propofol safely if given by non-anesthesia providers. J Clin Bioanal Chem.2018; Volume 2 Issue 1.

3. Sarkar, Manjula Sudeep, Desai, Pushkar M., Sageer, Hashim., Sarkar, Shubhra. Propofol LCT vs propofol MCT-LCT: Randomized controlled trial. Indian Journal of Clinical Anaesthesia, 2016; 3(2):214-218

4. Sahinovic, Marko M., Struys, Michel M.R.F. Absalom, Anthony R. Clinical Pharmacokinetics and Pharmacodynamics of Propofol. Clinical Pharmacokinetics, 2018; 57(12), 1539-1558.

5. Sim, J. Y., et al. Pain on injection with microemulsion propofol. British journal of clinical pharmacology. 2009; 67(3), 316325.doi:10.1111/j.1365-2125.2008.03358.

6. Liljeroth E. Pain induced by propofol-clinical studies on drug composition and administration. Sweden: Malmo University Hospital. 2007; p:5.

7. Deseusa, K.A. Pain on Propofol Ijection : Causes and Remedies. Indian $\mathrm{J}$ Pharmacol. 2016; vol 48(6) pp:617-623

8. Singh, D., Jagannath, S., Priye, S., Shivaprakash, Kadli, C., \& Reddy, D. Prevention of propofol injection pain: Comparison between lidocaine and ramosetron. Journal of anaesthesiology, clinical pharmacology. 2014; 30(2), 213-216. doi:10.4103/0970-9185.130023

9. Khezri MB, Kayalha $H$. The effect of combined ephedrine and lidocaine pretreatment on pain and hemodynamic changes due to propofol injection. Acta Anaesthesiologica Taiwanica. 2011; 49:54-58

10. Pereira Limberger, Renata \& Laura Bemvenuti Jacques, Ana \& Cristina Schmitt, Gabriela \& Arbo, Marcelo. Pharmacological Effects of Ephedrine. 2013; 10.1007/978-3642-22144-6_41. pp:1225-1226

11. Cetinkaya, Dilek \& Balaban, Onur \& Aydin, Tayfun \& Tulgar, Serkan \& Sabuncu, C. Can adding Ephedrine to Admixture of Propofol \& Lidocaine Overcome Propofol Associated Hemodynamic Changes and Injection Pain. International Journal of Anesthesiology \& Research. 2016; 4. 10.19070/2332-27801600049. p:214 
12. Afifuddin, Sitanggang, R.H., Oktaliansah, Ezra. Perbandingan Pem-berian Efedrin 30 $\mathrm{mcg} / \mathrm{kgBB}$ dengan Efedrin $70 \mathrm{mcg} / \mathrm{kgBB}$ Intravena terhadap Skala Nyeri dan Efek Hipotensi pada Penyuntikan Propofol di RSUP Dr. Hasan Sadikin Bandung. Jurnal Anestesi Perioperatif. 2017; 5 (3). 147-54

13. Weinberg L, Peake B, Tan C and Nikfarjam M. Pharmacokinetics and pharmacodynamics of lignocaine: A review. World Journal of Anesthesiology. 2015; vol 4(2). pp:17-29

14. Hadinata, Yudi. Perbandingan Premedikasi Lidokain Perlakuan Torniket Dan Campuran Lidokain untuk Mengurangi Derajat Nyeri Saat Induksi Anestesi Menggunakan Propofol di RSSA Malang. Fakultas Kedokteran. Jakarta:Universitas Indonesia;2013. pp 15-18

15. Syarif, Amir dan Sunaryo. Farmakologi dan Terapi Edisi 5. Jakarta : Balai Penerbit FK UI. 2013; p 265

16. Yuan-Yi, C., Lok-Hi, C., Chun-Chieh, H., Liu, K., Luo-Ping, G., \& Pei-Ning, W. Gender and pain upon movement are associated with the require-ments for postoperative patientcontrolled iv analgesia: a prospective sur-vey of 2,298 Chinese patients. Canadian Journal of Anesthesia, 2012; 49, 249-255.

17. Hye-Joo Kang, Mi-Young Kwon, corresponding author Byoung-Moon Choi, Min-Seok Koo, Young-Jae Jang, and Myoung-Ae Lee. Clinical factors affecting the pain on injection of propofol. Korean $\mathbf{J}$ Anesthesiol. 2010; 58(3): 239-243.

18. Mujahidin, Suryono Bambang, Uyun Yusmein. Comparison of the efficacy of ephedrine and lidocaine for reducing pain on propofol injection in Indonesian adult surgical patients. J Med Sci. 2013. Volume 45, No. 1 ; 20-26. 